1391 BLOOD UREA NITROGEN CONCENTRATION DURING EARLY AND AGGRESSIVE PARENTAL AMINO ACID ADMINISTRATION IN EXTREMELY LOW BIRTH WEIGHT INFANTS

doi:10.1136/archdischild-2012-302724.1391

${ }^{1} \mathrm{HJ}$ Lee, ${ }^{2} \mathrm{CW}$ Choi. ${ }^{1}$ Hanyang University College of Medicine, Seoul; ${ }^{2}$ pediatrics, Clinical Research Institute, Seoul National University Bundang Hospital, Seongnam, Republic of Korea

Background and Aims Early administration of parenteral amino acids (AA) has been shown to limit catabolism and improve growth in extremely low birth weight (ELBW) infants. This study aimed to evaluate an earlier, more aggressive administration of amino acids, was safe and well-tolerated, without clinically significant differences in metabolic acidosis or blood urea nitrogen (BUN).

Methods The 46 ventilator-dependent preterm infants less than $1000 \mathrm{~g}$ were retrospectively enrolled. The Early group received $\geq 3 \mathrm{~g} /$ $\mathrm{kg} / \mathrm{d}$ amino acids, while the Late group did not received a minimum of $\geq 3 \mathrm{~g} / \mathrm{kg} / \mathrm{d}$ parenteral $\mathrm{AA}$ at $\leq 3$ days of age.

Results An earlier, more aggressive administration of amino acids $(\geq 3 \mathrm{~g} / \mathrm{kg} / \mathrm{d}$ amino acids at $\leq 3$ days of age), was safe and welltolerated, without clinically significant differences in metabolic acidosis or BUN. There is no correlation between amino acid intake and BUN in ELBW infants within 7 days of life, Using multiple regression analysis, gestational age showed a significant negative correlation with BUN concentrations in ELBW infants within 7 days of life.

Conclusions High BUN in the early postnatal period might be related not only to amino acid oxidation and the infant's immaturity but also additional combined factors other than amino acid intolerance. Future studies are required to determine whether early and aggressive administration of amino acids is enough for optimal growth and neurodevelopmental outcome of ELBW infants.

\section{DOES ENTERAL PROTEIN INTAKE AFFECT RENAL GLOMERULAR AND TUBULAR FUNCTIONS IN VERY LOW BIRTH WEIGHT INFANTS?}

doi:10.1136/archdischild-2012-302724.1392

HG Kanmaz, B Mutlu, 0 Erdeve, FE Canpolat, SS Oguz, N Uras, U Dilmen; Zekai Tahir Burak Maternity Teaching Hospital, Ankara, Turkey

objectives and aim: Very low birth weight infants require 3-4 g/ $\mathrm{kg} /$ day protein intake to provide satisfactory postnatal growth rates and neurodevelopmental outcomes however they have fewer functional nephrons thereby, increasing vulnerability to impaired renal functions. The aim of this study was to investigate the effect of different amounts of enteral protein intake during the fortification of human milk on renal glomerular and tubular functions.

Material and Methods Preterm infants were randomized into three groups regarding their daily protein intakes as standard fortification $(3 \mathrm{~g} / \mathrm{kg} / \mathrm{d})$, moderate fortification $(3.3 \mathrm{~g} / \mathrm{kg} / \mathrm{d})$ and aggressive fortification $(3.6 \mathrm{~g} / \mathrm{kg} / \mathrm{d})$ groups. Serum urea, creatinin $(\mathrm{Cr})$, Cystatin $C$ (Cys-C) and urinary $\beta 2$ microglobulin $(\beta 2 \mathrm{M})$ levels were assessed and compared between groups.

Results Serum urea, Cr, Cys- $C$ and urinary $\beta 2 \mathrm{M}$ levels were similar in all three groups both on discharge and postnatal day 14 $(p>0.05)$. Mean $\mathrm{Cr}$ and $\beta 2 \mathrm{M}$ levels were significantly lower on discharge $(p<0.05)$ while Cys-C levels did not differ in time $(\mathrm{p}>0.05)$

Conclusion Enteral protein intake up to $3.6 \mathrm{~g} / \mathrm{kg} / \mathrm{d}$ did not altered the tubular and glomerular functions in very preterm infants. However, the long term renal effects in these infants maintained on a high protein intake remain unknown and should be addressed in future studies.

\section{REGIONAL STUDY FOR PREDICTIVE FACTORS OF BREASTFEEDING PRETERM INFANTS LESS THAN 33 WEEKS}

doi:10.1136/archdischild-2012-302724.1393

${ }^{1} \mathrm{C}$ Lucas, ${ }^{2} \mathrm{H}$ Gonny, ${ }^{3,4} \mathrm{C}$ Tripon, ' $\mathrm{K}$ Husseini, 'D Lapeyre, ${ }^{1} \mathrm{~F}$ Hay-Findler, ${ }^{1} \mathrm{~S}$ Robert. ${ }^{1}$ Pediatric Intensive Care Unit; ${ }^{2}$ Obstetrics; ${ }^{3}$ Neonatology, University Hospital of Poitiers, Poitiers; " ${ }^{2}$ Department of Neonatology, General Hospital of Angoulême, Angoulême, France

Objective To determine regional prevalence of breastfeeding very premature infants and identify factors influencing it's initiation at birth and continuation at discharge.

Study Design It was a prospective observational study in preterm $<33$ weeks of gestational age (GA) from January to December 2010 in Poitou-Charentes. Data were collected from infant report and using a questionnaire sent at home. The variables were analyzed with the $\mathrm{Chi}^{2}$ test and Student's $t$ test at $\mathrm{p}<0.05$ and binary logistic regression for predictive factors.

Results Questionnaires collected concerns 112/150 infants (74.7\%) and 95 parents (17 multiple pregnancy). At birth, 65.2\% $(n=73)$ were breastfed. Factors significantly associated with breastfeeding at birth were: maternal body mass index (BMI), employed mothers, mothers that have been breastfed (MoBr) and daycare other than grandparents. In a multivariate regression model, BMI, daycare by grandparents and $\mathrm{MoBr}$ were independent predictive factors of breastfeeding at birth with OR [IC 95\%]: 1.18 [1.011.38], 0.24 [0.08-0.74] and 5.8 [1.49-22.56] respectively. At discharge, $46.4 \%(n=52)$ of infants were breastfed. Factors significantly associated with breastfeeding at discharge were: intrapartum information about breastfeeding employed mothers, non smoker mothers, low paternal BMI, high educational level of fathers, daycare by grandparents, and $\mathrm{MoBr}$. The last 4 factors were independent predictors of breastfeeding at discharge in a multivariate binary logistic model with OR [IC 95\%]: 0.75 [0.62-0.9], 5.35 [1.24-23.1], 0.18 [0.03-0.96] and 7.5 [1.35-41.8] respectively.

Conclusion Socio-economic, educational and family conditions influence differently breastfeeding initiation and continuation. This diagnosis is precious to breastfeeding promotion programs.

\section{WEIGHT GAIN IN BABIES OF 28-32 WEEKS GESTATIONAL AGE; IMPACT OF A STANDARDISED ENTERAL FEEDING REGIME}

doi:10.1136/archdischild-2012-302724.1394

D Metheniti, A Papandreou, CS Narayanan. Neonatal Intensive Care Unit, West Hertfordshire Hospitals NHS Trust, Watford, UK

Background and Aims Earlier studies have shown that optimal early neonatal growth improves neurodevelopmental outcomes in preterm infants. A standardised enteral feeding regime (SEFR) was introduced across a UK neonatal network in April 2011. Effects of this standardisation on early neonatal growth are examined in our observational study.

Methods We retrospectively compared two cohorts of babies born in our unit at 28-31+6 weeks gestation during two epochs, one before and one after implementation of SEFR. Epoch1 extended between April and December 2010, Epoch2 between April and December 2011. Patients who were transferred in or out of the unit for continuation of care were excluded.

Results 20 patients were included in Epoch1(E1), 16 in Epoch2(E2). Baseline characteristics (gestation, birth weight, neonatal care) were similar between groups. E1 cohort regained birth weight in 11.65(6-17) days, reaching full enteral feeds at 7.3(2-18) days. E2 cohort regained birth weight in 11.06(5-18) days and reached full feeds at 7.88(5-15) days. TPN was used in $65 \%(n=13 / 20)$ of E1 cohort for $6.7(1-12)$ days and in $87.5 \%(n=14 / 16)$ of E2 cohort for 